\title{
Innovative greenhouse cultivation in compost barn
}

\author{
S. Friis Pedersen a and M. Ebbesvik \\ NORSOK, Norwegian Centre for Organic Agriculture, Tingvoll, Norway.
}

\begin{abstract}
This paper describes a new method in Norway for composting and its use for cultivation of plants in greenhouse. The composting is performed in a combined stable and greenhouse directly in the deep litter which is a mixture of cow manure and wood chips - a compost barn. This method is known in USA, Israel and the Netherlands. A newly constructed compost barn with 18 suckle cows was followed by four visits and samplings during 2017 and 2018 . The focus was on compost quality for growth media and the plant growth performance. During summertime, when cattle were outdoors, tomato Lycopersicum esculentum, pumpkin Cucurbita maxima and squash Cucurbita pepo were cultivated. Compost was analysed for nutrients at the beginning and the end of season. Compost maturity was evaluated using different standards and methods such as sprout inhibitions, the Solvita ${ }^{\circledR}$ method and sensory assessment. The results showed a high compost $\mathrm{pH}$. The compost $\mathrm{C}: \mathrm{N}$ ratio was reasonable for plant cultivation but, it could be lower by letting the compost mature for more time. The temperature in the compost during the composting process was lower than expected. The evaluation of compost maturity indicated stable and mature compost. The challenge of cultivation directly in the compost seems achievable. During the first growing season, the compost seemed too moist and consequently there was a sciarid Sciaridae spp. flie plague. During the second season, the compost seemed too dry and consequently attracted mould. According to the farmers, the management of cattle using this system was comparable to conventional management in terms of the time and effort required. Animal welfare was no issue. A suggestion to improve compost quality is to add more woodchips from broadleaved trees to reduce the compost $\mathrm{pH}$. It was concluded that using compost barns as greenhouses is promising and could be implemented in agroecological systems.
\end{abstract}

Keywords: agroecology, growth media quality, integrated animal/plant production

\section{INTRODUCTION}

Norway aims, like other countries, to phase out the use of peat in growth media. One of the most important alternatives is compost. "Compost" derives from "composing" and refers to microbial decomposition of fresh organic matter to form a stable organic residue. Many methods and materials for composting exist and can be practised. This fact leads to large differences in the quality of the final compost product. Final compost product can be used for several purposes and consequently different quality criteria are used. Compost for soil amendment is becoming more commonly used (Hatleli, 2012). However, compost for growth media is still a challenge due to differences in quality. Nevertheless, an international consensus on quality criteria for traded compost is not available (Brinton, 2000; Stentiford and Sánchez-Monedero, 2016). In Norway there is an ongoing revision of quality parameters and following new parameters can be developed (Måge, 2017).

A method of composting directly in the greenhouse that also serves as a cow stable was examined in this project. Composting process of a mixture of wood chips and animal manure, during winter, was sped up by harrowing twice a day while animals were fed outside. The challenges to produce effective compost are:

- To speed up composting process to get it mature and stable enough for the crop cultivation season;

aE-mail: susanne.friis.pedersen@norsok.no 
- To achieve the right humidity, temperature, $\mathrm{pH}, \mathrm{C}: \mathrm{N}$ ratio and content of available plant nutrients in the compost;

- To find reliable quality parameters.

\section{MATERIALS AND METHODS}

Daily and weekly routines during composting process was described and evaluated. Soil samples from two layers $(0-15$ and $15-30 \mathrm{~cm})$ were taken before and after the crop cultivation season in May and September. The samples were analysed for $\mathrm{pH}, \mathrm{C}: \mathrm{N}$, dry matter, content of nitrogen $(\mathrm{N})$, phosphorus $(\mathrm{P})$, potassium $(\mathrm{K})$, magnesium $(\mathrm{Mg})$ and calcium $(\mathrm{Ca})$ by EN and ISO standard methods.

Compost maturity was evaluated by testing sprout inhibition of cress Lepidium sativum, which is an often-used method for evaluation of compost maturity (Røthe, 2007; CCME, 1996). Fifty seeds were sown in two repetitions from each layer. Viable sprouts were counted and photographed on second, fourth, seventh and fourteenth day. To determine whether the compost was mature and of good quality, there needs to be 41 small plants standing on the $14^{\text {th }}$ day.

Emission of carbon dioxide $\left(\mathrm{CO}_{2}\right)$ and ammonium $\left(\mathrm{NH}_{3}\right)$ from the compost samples was measured according to Solvita ${ }^{\circledR}$ method (Solvita, 2018). Homogenous soil sample from the two layers $(0-15$ and $15-30 \mathrm{~cm})$ were in room temperature added a colour probe and after four hours written into a five scaled index of maturity degrees. The method has been scientifically validated and is used in commercial agriculture in the USA and in the composting sector in general, but it is little known in Norway (Brinton, 2000; Blytt and Åkesson, 2016; Solvita, 2019).

Sensory assessment was conducted. Colour was visually identified and rated. Tactile assessment of humidity was assessed by the first test (Fuchs et al., 2016). Olfactory assessment was conducted by the detection of smell at room temperature (Fuchs and Janmaat, 2016). The methods rely on human senses and can easily be implemented in the field. It was recommended by several scientists cooperating in the COST Action FA1105 Bio greenhouse (Van der Wurff et al., 2016).

In order to assess degree of turnover of raw material $1 \mathrm{~L}$ of raw material and ending compost sieved through a $0.8 \times 0.8 \mathrm{~mm}$ netting. This method was suggested for a norm in a coming manual for compost quality in Norway (Blytt and Åkesson, 2016).

\section{RESULTS}

Planted squash and tomato did well during first growing season. An attack of sciarid flies was controlled but any other pests were not detected. Directly sown seeds did not perform well in the first year. During the second growth season, the compost seemed rather dry. Pumpkins and squash did well, and tomatoes performed reasonably well.

The results from the analysis are shown in Table 1.

Table 1. Results from the analysis of chemically properties and nutrient contents in a sample of both layers from the compost barn.

\begin{tabular}{lcc}
\hline Characteristics & May 2018 & September 2018 \\
\hline $\mathrm{pH}$ & 8.8 & 8.6 \\
$\mathrm{C}: \mathrm{N}$ ratio & 28 & 22 \\
Dry matter content (\%) & 41.0 & 30.8 \\
Total-nitrogen $\left(\mathrm{g} \mathrm{L}^{-1}\right)$ & 2.60 & 2.30 \\
Phosphorus, $\mathrm{P}-\mathrm{AL}\left(\mathrm{g} \mathrm{L}^{-1}\right)$ & 0.74 & 0.20 \\
Potassium, $\mathrm{K}-\mathrm{AL}\left(\mathrm{g} \mathrm{L}^{-1}\right)$ & 4.14 & 0.18 \\
Magnesium, $\mathrm{Mg-AL} \mathrm{(g} \mathrm{L-1)}$ & 0.33 & 0.02 \\
Calcium, Ca-AL $\left(\mathrm{g} \mathrm{L}^{-1}\right)$ & 2.70 & 0.10 \\
\hline
\end{tabular}

The results from evaluation of plant inhibition showed the best performance of sprouts in September in both years, in both layers. In 2018, the sprout germination percentage was 
respectively 88 and $98 \%$ in relation to the two layers $(0-15$ and $15-30 \mathrm{~cm})$. Temperature in the room varied in the two tests in 2017 and the first in 2018 from 10 to $25^{\circ} \mathrm{C}$. During the second test in 2018 it was steady between 19 and $21^{\circ} \mathrm{C}$.

The results from the Solvita ${ }^{\circledR}$ test showed that emissions of $\mathrm{NH}_{3}$ and $\mathrm{CO}_{2}$ were low. The colours of the probes indicated thereby that the compost was not active but practically mature.

The results of the sensory assessment were that visually the colour was lighter in the deepest layer from the $15-30 \mathrm{~cm}$ depth, and that there was no smell from any of the samples. Dry matter content in the upper layer was $40-50 \%$ and in the deepest layer $37-48 \%$ medians of six repetitions performed twice a year in 2017 and 2018. It was concluded that the compost was generally driest in the upper layer.

The results from sieving through a netting showed that $35 \%$ of the raw material passed through and, respectively, $85-87 \%$ in 2017 and $91-93 \%$ in 2018 of the end-compost. The highest percentage according to the deepest layer both years.

\section{DISCUSSION}

The pH-level was rather high (8.8 and 8.6) and consequently the uptake of plant nutrients can have been affected. To prevent this, magnesium sulphate was added, and the $\mathrm{pH}-$ level dropped slightly. In order to bring down $\mathrm{pH}$ level it could have been considered to incorporate more wood chips from broadleaved trees rather than conifers without elevating the C: $\mathrm{N}$ ratio. There is some evidence, that pine wood chip of any age would increase $\mathrm{pH}$ (Owen et al., 2017). The C:N ratio (28 and 22) is close to the mean C:N ratio 18.7 reported from a review of articles covering 71 different composts from temperate and tropical climate (Faverial et al., 2016). The level of plant nutrients was rather high too (Table 2). An optimum for phosphorus in soil would be 8-14 $\mathrm{mg} \mathrm{L}^{-1}$, for potassium 7-30 $\mathrm{mg} \mathrm{L}^{-1}$, for magnesium 3-5$\mathrm{mg} \mathrm{L}^{-1}$ and calcium 50-99 $\mathrm{mg} \mathrm{L}^{-1}$ (Eurofins, 2019). Maybe the high $\mathrm{pH}$ level inhibited the plant nutrient uptake in the crop but there was plenty of it. No severe nutrient poisoning or lack of nutrients were detected in 2017 nor in 2018.

Table 2. Plant nutrient content from the compost from the compost barn compared to other products.

\begin{tabular}{lccccc}
\hline & $\begin{array}{c}\text { Total } \\
\text { nitrogen } \\
\left(\mathbf{m g ~ L}^{-1}\right)\end{array}$ & $\begin{array}{c}\text { Phosphorus } \\
\text { P-AL } \\
\left(\mathbf{m g ~ L}^{-1}\right)\end{array}$ & $\begin{array}{c}\text { Potassium } \\
\text { K-AL } \\
\left(\mathbf{m g ~ L}^{-1}\right)\end{array}$ & $\begin{array}{c}\text { Magnesium } \\
\text { Mg-AL } \\
\left(\mathbf{m g ~ L}^{-1}\right)\end{array}$ & $\begin{array}{c}\text { Calcium } \\
\text { Ca-AL } \\
(\mathbf{m g ~ L}-1)\end{array}$ \\
\hline Compost from compost barna & 2600 & 740 & 4140 & 330 & 2700 \\
Commercial products & $150-1100$ & $18-90$ & $200-500$ & $165-200$ & $250-1500$ \\
Recommended value in Germany & $-\mathrm{c}$ & $<1200$ & $<2000$ & $-\mathrm{c}$ & $-\mathrm{c}$ \\
Recommended value in Austria & $-\mathrm{c}$ & $<800$ & $<1500$ & $-\mathrm{c}$ & $-\mathrm{c}$ \\
"Recommended" value in USA & $-\mathrm{c}$ & $800-2500$ & $500-2000$ & $-c$ & $-c$ \\
\hline
\end{tabular}

aAnalysis from May 2018.

bMinimum and maximum values from commercial products in Norway are standards from Norwegian Ecopeat, Änglamark, Haslefors ecosoil, Weibull sowing soil.

cValue not given.

Compared to commercial growth media products, the compost had high contents of nitrogen, phosphor, potassium, magnesium and calcium (Table 2).

A recommendation in traded compost products exists in Germany and Austria. USA has "recommended" values referring to declaration standards (Brinton, 2000).

Another aspect to quality evaluation is that growing media must be homogeneous which this compost was but, it is often reported that composted material often is highly heterogeneous (Ní Chualáin et al., 2017).

To speed up the composting process wood chips could have been defibred wood instead of cutted wood. Defibring could be uptained by steaming, chemically or mechanically processing and implies a larger surface of the chips. Larger surface gives a larger opportunity for microbial organism activity and consequently a faster composting process. 
The sprout tests provided best results in September 2018 in both layers, that maybe due to that it was performed in the oldest compost. Nevertheless, on the $14^{\text {th }}$ day some of the small sprouts were damped off maybe because of Pythium or Fusarium.

The sieving procedure could had been divided into more fractions.

\section{CONCLUSIONS}

The many possibilities for raw materials, methods of composting and different quality parameters makes it difficult to compare and evaluate quality of compost. Anyway, several parameters for quality control must be applied.

The properties of the compost from the compost barn are in this case not yet appropriate for plant cultivation in general. Nevertheless, pumpkins and squash performed moderately well. Tomato cultivation could, if early cultivars where chosen, do the same.

Anyway, the challenges seem reasonable to overcome, and compost barn for animal and plant husbandry may in the future be a sustainable option for farmers.

\section{ACKNOWLEDGEMENTS}

We would like to thank Erik and Cornelia Gran on the Gran Nordre Farm for their pioneer work and openness to allow us in. Without them this paper would not have been possible.

\section{Literature cited}

Blytt, L.D., and Åkesson, R. (2016). Beste praksis for kompostering av hageavfall. Rapport no. 3 (Avfallnorge), pp.37.

Brinton, W.F. (2000). Compost Quality in America. Compost Quality, Standards \& Guidelines (Woods End Res. Laboratory Inc. Prepared for New York State Assoc. of Recyclers), pp.42.

CCME. (1996). Guidelines for Compost Quality (Canadian Council of Ministers of the Environment), pp.11.

Eurofins. (2019). Veiledning til jordanalyser. www. cdnmedia.eurofins.com/europeaneast/media/356784/veiledning-jord.pdfhttps://cdnmedia.eurofins.com/european-east/media/356784/ veiledning-jord.pdf.

Faverial, J., Boval, M., Sierra, J., and Sauvant, D. (2016). End-product quality of composts produced under tropical and temperate climates using different raw materials: a meta-analysis. J Environ Manage 183 (Pt 3), 909-916 https://doi.org/10.1016/j.jenvman.2016.09.057. PubMed

Fuchs, J.G., and Janmaat, L. (2016). How growers can assess compost quality? In Handbook for Composting and Compost Use in Organic Horticulture, A.W.G. Van der Wurff, J.G. Fuchs, M. Raviv, and A.J. Termorshuizen, eds. BioGreenhouse COST Action FA 1105, p.99-104.

Fuchs, J.G., Janmaat, L., and Raviv, M. (2016). What control measures do we need for compost production and use. In Handbook for Composting and Compost Use in Organic Horticulture, A.W.G. Van der Wurff, J.G. Fuchs, M. Raviv, and A.J. Termorshuizen, eds., BioGreenhouse COST Action FA 1105, p.53-62.

Hatleli, L. (2012). Kvalitetskompost til Bruk i Frukt- og Bærhagar. Litteraturstudie. Prosjekt "Kvalitetskompost til Frukt- og Bærhagar" (NJøS Næringsutvikling), pp.15.

Måge, J. (2017). ECN Country Rep. 2017 Norway (European Compost Network), pp.7.

Ní Chualáin, D., Hynes, C., Lombard, S., McDaniel, N., Carlile, B., O’Haire, R., and Doyle, O. (2017). Quality control of growing media for retail markets. Acta Hortic. 1168, 287-294 https://doi.org/10.17660/ActaHortic.2017. 1168.37.

Owen, W.G., Jackson, B.E., and Fonteno, W.C. (2017). Pine wood chip aggregates for greenhouse substrates: effect of age on plant growth. Acta Hortic. 1168, 269-276 https://doi.org/10.17660/ActaHortic.2017.1168.35.

Røthe, G. (2007). Potteforsøk - Flisblandet Husdyr Gjødsel. Prosjekt Flisunderlag til Husdyr (Bioforsk Nord Holt), p.8.

Solvita. (2018). www. solvita.com/compost/.

Solvita. (2019). www. solvita.com/solvita-achieves-publishing-milestone-more-than-80-journal-articles/.

Stentiford, E., and Sánchez-Monedero, M.A. (2016). Past, present and future of composting research. Acta Hortic. 1146, 1-10 https://doi.org/10.17660/ActaHortic.2016.1146.1.

Van der Wurff, A.W.G., Fuchs, J.G., Raviv, M., and Termorshuizen, A.J., eds. (2016). Handbook for Composting and 
Compost Use in Organic Horticulture. BioGreenhouse COST Action FA 1105, pp.108. 
